\title{
Perspectives of Biomedical Application of Macrofungi
}

\author{
Susanna M Badalyan ${ }^{1 *}$ and Sylvie Rapior ${ }^{2 *}$ \\ ${ }^{1}$ Laboratory of Fungal Biology and Biotechnology, Institute of Pharmacy, Department of Biomedicine, Yerevan State University, Armenia \\ ${ }^{2}$ Laboratoire de Botanique, Phytochimie et Mycologie, Faculté de Pharmacie, CEFE CNRS - Université de Montpellier - Université Paul-Valéry \\ Montpellier - EPHE - IRD, Montpellier, France
}

Submission: March 13, 2020; Published: July 29, 2020

*Corresponding author: Badalyan SM, Laboratory of Fungal Biology and Biotechnology, Institute of Pharmacy, Department of Biomedicine, Yerevan State University, Yerevan, Armenia, Email: s.badalyan@ysu.am

Rapior S, Laboratoire de Botanique, Phytochimie et Mycologie, Faculté de Pharmacie, CEFE CNRS - Université de Montpellier - Université PaulValéry Montpellier - EPHE - IRD, Montpellier, France, Email: sylvie.rapior@umontpellier.fr

Abstract

Macrofungi (mushrooms) have widely been appreciated all over the world for their nutritional values and medicinal properties. They have been used in traditional medicine for more than 3000 years for prevention and treatment of different diseases. Modern scientific research shows that macrofungi are producers of a broad spectrum of high- and low-molecular-weight bioactive compounds, i.e., alkaloids, polysaccharides, proteins, phenolics, terpenoids, polyketides, cyclic peptides, lectins and ribosome-inactivating proteins. They have various therapeutic effects as antidiabetic, anti-inflammatory, antimicrobial, antioxidant, antitumor, antiviral, cardioprotective, hepatoprotective, hypocholesterolemic, hypotensive, immunomodulatory, neuroprotective and regenerative, and possess promising pharmacological potential. Development of fungal biotechnological cultivation industry will support production of macrofungi-derived biotech products, healthy food and mycopharmaceuticals pharmaceuticals. Further advances in fungal biology and biotechnology, genomics and proteomics will assist biomedical research and application of macrofungi.

Keywords: Medicinal macrofungi; Basidiomycota; Ascomycota; Bioactive compounds; Pharmacological effect; Biomedicine

Abbreviations: BAC: Bioactive Compounds; FIP: Fungal Immunomodulatory Protein; MM: Medicinal Macrofungi

\section{Introduction}

Fungi are very diverse organisms distributed worldwide and found in almost all habitats. From estimated 1.5-3 million species of fungi about 150,000 species are macrofungi (mushrooms) taxonomically placed in two phyla, the Basidiomycota (class Agaricomycetes) and Ascomycota (class Pezizomycetes) in the subkingdom Dikarya [1]. Among them about 10\% (14,000$16,000)$ are scientifically well-known including, about 7000 edible species and 500 poisonous species [2,3]. There may be as many as 700 medicinal macrofungi (MM) which are regarded safe and possess around 130 different pharmacological activities [4,5].

Macrofungi have widely been appreciated all over the world not only for their nutritional values but also medicinal properties [5-12]. They have been used in traditional medicine for more than 3000 years for prevention and treatment of different diseases $[13,14]$. Despite available ethno-mycopharmacological information and scientific data the extensive pharmacological and biotechnological potential offered by Macrofungi is certainly not yet fully exploited [15-20].

\section{Bioactive Compounds and Pharmacological Activity of Macrofungi}

Modern scientific data shows that agaricoid, polyporoid, and other taxonomic groups of Macrofungi are producers of a broad spectrum of high- and low-molecular-weight bioactive compounds (BAC), i.e., alkaloids, polysaccharides, proteins, phenolics, terpenoids, polyketides, cyclic peptides, lectins, ribosomeinactivating proteins [21-27]. These BAC means Bioactive Compounds were investigated for their various therapeutic effects as analgesic, antimicrobial, antiviral, antioxidant, immunomodulatory, anti-inflammatory, antitumor, mitogenic/ regenerative, hypotensive, hepatoprotective, antidiabetic/ hypoglycemic, hypocholesterolemic, cardio- and neuroprotective activities [28-45].

Wild and cultivable edible, and non-edible MM (e.g. Agaricus brasiliensis, Agrocybe cylindracea, Auricularia auricula-judae, Coprinus comatus, Ganoderma applanatum, G. lucidum, Grifola frondosa, Hericium erinaceus, Flammulina velutipes, Inonotus 
obliquus, Lentinula edodes, Ophiocordyceps (syn. Cordyceps) sinensis, Phellinus linteus, Pleurotus ostreatus, Polyporus umbellatus, Trametes versicolor, Tremella fuciformis, Wolfiporia cocos, etc.) are considered as valuable sources to develop health enhancing functional food (nutraceuticals, nutriceuticals), macrofungi-derived drugs (mycopharmaceuticals), and cosmetic products (cosmeceuticals, nutricosmetics) which are perspective for biomedical application [12,18-20,46].

A wide spectrum of bioactive molecules with macrofungi origin has been recommended for a variety of therapeutic applications, such as the immunomodulatory $\beta$-glucan lentinan from $L$. edodes [27], the antimalarial alkaloid 4-hydroxymethylquinoline from $T$. versicolor [47]; pain-suppressive enkephalinase inhibitors from Piptoporus betulinus [48]; nephroprotective polysaccharides, phenolics, and flavonoids from Pleurotus tuber-regium [37].

The extract derived from well-known medicinal species Cordyceps sinensis and Agaricus subrufescens possess anticancer effects by modulating the immune system and inducing cell apoptosis [25,38]. The edible medicinal oyster mushroom $P$. ostreatus has significant hypocholesterolemic properties and other pharmacological effects $[30,39,40,43]$. Anticancer, antimicrobial, antioxidant, antiviral, hypolipidemic, immunomodulatory, and estrogen-like activities were observed in Pleurotus eryngii due to the production of diterpenoids, as eryngiolide $\mathrm{A}$, hemolysins, polysaccharides, pentacyclic triterpenoids, ubiquinone-9, and other pharmacologically active biomolecules [43,49,50]. Genome sequencing, comparative genomics, and phylogenetic analysis of medicinal polypore mushroom Lignosus rhinocerotis revealed sesquiterpenoid biosynthesis genes. Moreover, the genome of $L$. rhinocerotis encodes for 1,3- $\beta$ - and 1,6- $\beta$-glucans, as well as for laccase, lectin, and other fungal immunomodulatory proteins (FIP) [51,52].

The Ganoderma species produce the highest diversity of bioactive compounds (alkaloids, fatty acids, nucleosides, polysaccharides, proteins, sterols, triterpenoids, etc.) with antiaging, antibacterial, anticancer, antidiabetic, antifungal, antihypertensive, anti-inflammatory, antioxidant, antiviral, hepatoprotective, hypoglycemic, immunomodulatory, neuroprotective, wound-healing, and other pharmacological effects $[22,23,32-34,41,42]$.

\section{Conclusion and Future Perspectives}

Nowadays, pharmaceutical companies consider the medicinal macrofungi as a rich source of innovative biomedical molecules extracted notonly from fruiting bodies butalso from both cultivated mycelial biomass and cultural broth. Moreover, the mycelium and the cultural broth might be considered as safe potential sources of bioactive compounds, due to their shorter incubation time and affordable culture conditions (e.g., requiring less space, low probability of contamination, and higher production of biomass) $[12,36,43]$.
The advances in multidimensional biotechnological cultivation industry of macrofungi will further support development and application of myco-biotech products biotech products and pharmaceuticals in biomedicine $[7,19,20]$.

Currently, in vitro assays, animal studies, and clinical trials justify the experience of traditional medicine and suggest a great potential of macrofungi-derived compounds and pharmaceuticals for both the prevention and treatment of various diseases. However, development of high-quality and safe biotech products under controlled conditions with standardized procedures for further clinical trials are needed to substantiate the pharmacological properties or side effects of mushroom consumption before their clinical recommendation as myco-pharmaceutical drugs [36,5356]. Compared to available extensive lists of bioactive compounds of macrofungi and their therapeutic effects and therapeutic effects, the pathways of their biosynthesis and the genes behind are largely understudied [19]. Therefore, advances in fungal biology and biotechnology, genomics and proteomics are required for further biomedical research and application of macrofungi.

\section{Acknowledgments}

This review arises from a long-standing cooperation between two authors (S.M.B. and S.R.) on fungal biomedical research directed to theidentification of bioactive compounds and medicinal properties of macrofungi supported by the collaboration between the Institute of Pharmacy; Yerevan State University, Armenia; and Faculty of Pharmacy of the University of Montpellier/UMR 5175 CNRS, France. The research project on medicinal mushrooms was partially sponsored by MES SCS Republic of Armenia (grant number \#18T-1F115).

\section{References}

1. Hibbett DS, Taylor JW (2013) Fungal systematics: is a new age of enlightenment at hand? Nat Rev Microbiol 11: 129-133.

2. Hawksworth DL (2001) Mushrooms: the extent of the unexplored potential. Int J Med Mushrooms 3: 333-337.

3. Hawskworth DL (2012) Global species numbers of fungi: are tropical studies and molecular approaches contributing to a more robust estimate? Biodivers Conserv 21: 2425-2433.

4. Boa ER (2004) Wild edible fungi a global overview of their use and importance to people. Food and Agriculture Organization of the United Nations, Roma.

5. Chang ST, Wasser SP (2017) The cultivation and environmental impact of mushrooms. In: Oxford research encyclopedia of environmental science - Agriculture and the environment.

6. Chang ST, Miles PG (2004) Mushrooms: Cultivation, nutritional value, medicinal effect, and environmental impact, 2nd edn. CRC Press, Boca Raton.

7. Chang ST, Buswell JA (1996) Mushroom nutriceuticals. World J Microbiol Biotechnol 12(5): 473-476.

8. Wasser SP (2014) Medicinal mushroom science: current perspectives, advances, evidences, and challenges. Biomed J 37(6): 345-356.

9. Valverde ME, Hernández-Pérez T, Paredes-López 0 (2015) Edible mushrooms: improving human health and promoting quality life. 
Intern J Microbiol ID 376387, 14 p.

10. Gupta S, Summuna B, Gupta M, et al. (2018) Edible mushrooms: cultivation, bioactive molecules, and health benefits. In: Mérillon JM Ramawat KG (Eds) Bioactive molecules in food, reference series in Phytochemistry. Springer, pp. 1-33.

11. Bandara AR, Rapior S, Bhat DJ, Pattana K, Sunita C, et al. (2015) Polyporus umbellatus, an edible-medicinal cultivated mushroom with multiple developed health-care products as food, medicine and cosmetics: a review. Cryptogam Mycol 36(1): 3-42.

12. Bandara AR, Rapior S, Mortimer PE, Kakumyan P, Hyde KD, et al. (2019) A review of the polysaccharide, protein and selected nutrient content of Auricularia, and their potential pharmacological value. Mycosphere 10(1): 579-607.

13. Hobbs CR (1995) Medicinal mushrooms: an exploration of traditions, healing, and culture. Botanica Press, Santa Cruz.

14. Chen H, Tian T, Miao H, Zhao YY (2016) Traditional uses, fermentation, phytochemistry and pharmacology of Phellinus linteus: a review. Fitoterapia 113: 6-26.

15. Lindequist $U$ (2013) The merit of medicinal mushrooms from a pharmaceutical point of view. Int J Med Mushrooms 15(6): 517-523.

16. Grienke U, Zöll M, Peintner U, et al. (2014) European medicinal polypores - a modern view on traditional uses. J Ethnopharmacol 154(3): 564-583.

17. De Silva DD, Rapior S, Sudarman E, Marc S, Jianchu X, et al. (2013) Bioactive metabolites from macrofungi: ethnopharmacology, biological activities and chemistry. Fungal Divers 62: 1-40.

18. Badalyan SM (2012) Medicinal aspects of edible ectomycorrhizal mushrooms. In: Zambonelli A \& Bonito G (Eds) Edible ectomycorrhizal mushrooms, current knowledge and future prospects. Vol. 34 Springer/Heidelberg, pp. 317-334.

19. Kües U, Badalyan SM (2017) Making use of genomic information to explore the biotechnological potential of medicinal mushrooms. In Agrawal DC, et al. (Eds). Medicinal plants and fungi: recent advances in research and development. In book series Medicinal and aromatic plants of the world Vol. 4. Springer Nature Singapore, pp 397-458.

20. Badalyan SM, Zambonelli A (2019) Biotechnological exploitation of macrofungi for the production of food, pharmaceuticals and cosmeceuticals. In: Sridhar KR, Deshmukh SK (Eds) Advances in macrofungi: diversity, ecology and biotechnology. Boca Raton, CRC Press, pp. 199-230.

21. Xu X, Yan H, Chen J, Zang X (2011) Bioactive proteins from mushrooms. Biotechnol Adv 29(6): 667-674.

22. Sánchez C (2017) Bioactives from mushrooms and their application. In: Puri M (Ed) Food bioactives. Springer-Verlag, pp. 23-57.

23. Yang YL, Tao QQ Han JJ, et al. (2017) Recent advance on bioactive compounds from the edible and medicinal fungi in China. In: Agrawa DC, et al. (Eds) Medicinal plants and fungi: recent advances in research and development, Medicinal and aromatic plants of the world. Springer Nature Singapore, pp. 253-313.

24. Pandya U, Dhuldhaj U, Sahay NS (2018) Bioactive mushroom polysaccharides as antitumor: an overview. Nat Prod Res 4: 1-13.

25. Da Silva de Souza AC, Corrěa VG, Goncalves GA, et al. (2017) Agaricus blazei bioactive compounds and their effects on human health: benefits and controversies. Curr Pharm Des 23(19): 2807-2834.

26. Wang Q, Wang F, Xu Z, Ding Z (2017) Bioactive mushroom polysaccharides: a review on monosaccharide composition, biosynthesis and regulation. Molecules 22: 955.

27. Novak M, Vetvicka V (2008) $\beta$-Glucans, history, and the present: immunomodulatory aspects and mechanisms of action. J Immunotoxicol 5(1): 47-57.

28. Morel S, Arnould S, Vitou M, Boudard F, et al. (2018). Antiproliferative and antioxidant activities of wild Boletales mushrooms from France. Int J Med Mushrooms, 20(1): 13-29.

29. Diallo I, Boudard F, Morel S, Vitou M, et al. (2020) Antioxidant and antiinflammatory potential of Lentinula edodes (Shiitake) sporophores from various culture conditions. Int J Med Mushrooms 22 22(6): 535546.

30. Thongbai B, Rapior S, Hyde KD, Wittstein K, Stadler M (2015) Hericium erinaceus, an amazing medicinal mushroom. Mycological Progress 14(10), Article 91

31. Chen CC, Shiao YJ, Lin RD, et al. (2006) Neuroprotective diterpenes from the fruiting body of Antrodia camphorata. J Nat Prod 69: 689-691

32. De Silva DD, Rapior S, Fons F, et al. Medicinal mushrooms in supportive cancer therapies: an approach (2012a) to anti-cancer effects and putative mechanisms of action. Fungal Divers 55: 1-35.

33. De Silva DD, Rapior S, Hyde KD, et al. (2012b) Medicinal mushrooms in prevention and control of diabetes mellitus. Fungal Divers 56: 1-29.

34. Perera PK, Li Y (2011) Mushrooms as a functional food mediator in preventing and ameliorating diabetes. Funct Food Health Dis 4: 161171.

35. Xu H, Kong YY, Chen X, et al. (2016) Recombinant FIP-gat, a fungal immunomodulatory protein from Ganoderma atrum, induces growth inhibition and cell death in breast cancer cells. J Agric Food Chem 64:2690-2698.

36. Hyde KD, Jianchu Xu, Rapior S, Lumyong S, et al. (2019) The amazing potential of fungi, 50 ways we can exploit fungi industrially. Fungal Diversity 97:1-136, 1-136.

37. Okolo KO, Orisakwe OE, Siminialayi IM (2018) Nephroprotective and antioxidant effects of king tuber oyster medicinal mushroom, Pleurotus tuber-regium (Agaricomycetes), on carbon tetrachloride-induced nephrotoxicity in male Sprague dawley rats. Int J Med Mushrooms 20(5): 419-429.

38. Xu J, Huang Y, Chen XX, et al. (2016) The mechanisms of pharmacological activities of Ophiocordyceps sinensis fungi. Phytother Res 30:15721583.

39. Patel Y, Naraian R, Singh VK (2012) Medicinal properties of Pleurotus species (oyster mushroom): a review. World J Fungal Plant Biol 3:1-12.

40. Schillaci D, Cusimano MG, Cascioferro SM, et al. (2017) Antibacterial activity of desert truffles from Saudi Arabia against Staphylococcus aureus and Pseudomonas aeruginosa. Int J Med Mushrooms 19(2): 121-125.

41. Saltarelli R, Ceccaroli P, Buffalini M, et al. (2015) Biochemical characterization, antioxidant and antiproliferative activities of different Ganoderma collections. J Mol Microbiol Biotechnol 25(1): 1625.

42. Wang XL, Ding ZY, Zhao Y, et al. (2017) Efficient accumulation and in vitro antitumor activities of triterpene acids from submerged batchcultured Lingzhi or Reishi medicinal mushroom, Ganoderma lucidum (Agaricomycetes). Int J Med Mushrooms 19(5): 419-431.

43. Zhang C, Li S, Zhang J, et al. (2016) Antioxidant and hepatoprotective activities of intracellular polysaccharide from Pleurotus eryngii SI-04. Int J Biol Macromol 91: 568-577.

44. Taofiq O, Martins A, Barreiro MF, et al. (2016) Anti-inflammatory potential of mushroom extracts and isolated metabolites. Trends Food Sci Technol 50: 193-210. 
45. Souilem F, Fernandes Â, Calhelha RC, et al. (2017). Wild mushrooms and $\mathrm{RC}$, et al. their mycelia as sources of bioactive compounds: antioxidant, anti-inflammatory and cytotoxic properties. Food Chem 230: $40-48$

46. Taofiq O, González-Paramás AM, Martins A, et al. (2016) Mushrooms extracts and compounds in cosmetics, cosmeceuticals and nutricosmetics - a review. Ind Crop Prod 90: 38-48.

47. Liu JK (2005) N-containing compounds of macromycetes. Chem Rev 105(7): 2723-2744

48. Rathee S, Rathee D, Rathee D, Vikash K, Permender R, et al. (2011) Mushrooms as therapeutic agents. Bras J Pharmacognosy 22(2): 459474

49. Ma G, Yang W, Mariga AM, Yong F, Ning M, et al. (2014) Purification, characterization and antitumor activity of polysaccharides from Pleurotus eryngii residue. Carbohydr Polym 114: 297-305.

50. Yen MT, Chang YH, Huang SJ, Ming-Ching C, Jeng-Leun M, et al. (2018) Extraction of ergothioneine from Pleurotus eryngi and P. citrinopileatus (Agaricomycetes) and preparation of its product. Int J Med Mushrooms 20(4): 381-392.
51. Yap HY, Chooi YH, Firdaus-Raih M, Fung SY, Ng ST, et al. (2014) The genome of the tiger milk mushroom, Lignosus rhinocerotis, provides insights into the genetic basis of its medicinal properties. BMC Genomics 15(1): 635.

52. Yap HY, Fung SY, Ng ST, Tan CS, Tan NH (2015) Genome-based proteomic analysis of Lignosus rhinocerotis (Cooke) Ryvarden sclerotium. Int J Med Sci 12(1): 23-31.

53. Money NP (2016) Are mushrooms medicinal? Fungal Biol 120(4): 449453.

54. Wasser SP (2017) Medicinal mushrooms in human clinical studies. Part I. Anticancer, oncoimmunological, and immunomodulatory activities: a review. Int J Med Mushrooms 19(4): 279-317.

55. Badalyan SM, Barkhudaryan A, Rapior S (2019) Recent progress in research on the pharmacological potential of mushrooms and prospects for their clinical application. In: Agrawal DC \& Dhanasekaran M. (eds) Medicinal Mushrooms: Recent Progress in Research and Development. Springer Nature Singapore, pp 1-70.

56.Zmitrovich IV, Belova NV, Balandaykin ME, Bondartseva MA, Wasser SP (2019) Cancer without pharmacological illusions and a niche for Mycotherapy (review). Int J Med Mushrooms 21(2): 105-119.

\section{Your next submission with Juniper Publishers}

\section{will reach you the below assets}

- Quality Editorial service

- Swift Peer Review

- Reprints availability

- E-prints Service

- Manuscript Podcast for convenient understanding

- Global attainment for your research

- Manuscript accessibility in different formats

(Pdf, E-pub, Full Text, Audio)

- Unceasing customer service

Track the below URL for one-step submission

https://juniperpublishers.com/online-submission.php 